\title{
Association between Sleep Disturbance with Weight-for-Height and Body Mass Index in Preschoolers
}

\author{
Laili Nur Rosyidah ${ }^{1}$, Ahmad Suryawan $^{2 \star}$, Irfiansyah Irwadi ${ }^{3}$
}

${ }^{1}$ Faculty of Medicine, Universitas Airlangga, Surabaya, Indonesia.

${ }^{2}$ Department of Pediatrics, Faculty of Medicine, Universitas Airlangga/Dr. Soetomo General Hospital, Surabaya, Indonesia. ${ }^{3}$ Department of Physiology, Universitas Airlangga, Surabaya, Indonesia.

\section{A B S T R A C T}

Introduction: Hormonal changes affecting a child's growth occur in deep sleep phase of preschoolers. Nowadays, obesity is still a world health problem. In 2014, Indonesia had three growth problems, one of them was overweight in preschoolers. This study aimed to analyze the association between sleep disturbance with weightfor-height and body mass index (BMI) in preschoolers.

Methods: This was a cross-sectional study by analyzing the tendency with boxplot charts and the association was measured by Mann-Whitney test and independent ttest. Data of 86 preschoolers aged 3-5 years old were obtained from three kindergartens in Kalijudan, Surabaya from March to September 2018. Z-score values and the categories of weight-for-height Z-score (WHZ) and BMI-for-age Z-score (BAZ) refer to WHO Standards 2006 and sleep disturbances were measured by sleep disturbance scale for children (SDSC) questionnaire.

Results: $65.12 \%$ of preschoolers had sleep disturbance and $66.28 \%$ of them had normal $\mathrm{WHZ}$ and BAZ. The average $\mathrm{WHZ}$ and BAZ value in preschoolers who had sleep disturbance $(M=-0.2730 ;-0.2207)$ were higher than preschoolers who had no sleep disturbance $(M=-0.6083 ;-0,5920)$. Results from Mann-Whitney test showed the same significance value between $\mathrm{WHZ}$ and $\mathrm{BAZ}, \mathrm{p}=0.226$. Independent t-test showed a significance value of $p=0.524$ and $p=0.490$, meaning that there was no statistically significant association.

Conclusion: There was no statistically significant association between sleep disturbance with $\mathrm{WHZ}$ and BAZ in preschoolers aged 3-5 years old, however descriptively, the values of $\mathrm{WHZ}$ and $\mathrm{BAZ}$ in the group of preschoolers who had sleep disturbance tended to be higher.

\section{* Correspondence: suryawan.ahmad@gmail.com}

JUXTA: Jurnal IImiah Mahasiswa Kedokteran Universitas Airlangga

p-ISSN: 1907-3623; e-ISSN: 2684-9453

DOI: 10.20473/juxta.V12I12021.19-25

Open access under Creative Commons Attribution-ShareAlike 4.0 International License

(CC-BY-SA)

\section{ARTICLE INFO}

Article history:

Received 12 November 2020

Received in revised form 27

November 2020

Accepted 11 December 2020

\section{Keywords:}

Sleep disturbance,

Preschoolers,

Weight-for-height,

Body mass index. 


\section{Introduction}

Obesity is a world health problem as its prevalence has doubled from 1980 to 2014 worldwide. 41 million children under 5 years old are overweight or obese in $2014 .{ }^{1}$ Global Nutrition Report in 2014 showed that Indonesia is included in 17 out of 117 countries that have three growth disorders; stunting, wasting, and overweight in preschoolers. ${ }^{2}$

Growth in preschoolers, especially to assess overweight and obesity, can be measured by using weightfor-height and body mass index (BMI). ${ }^{3}$ World Health Organization (WHO) 2006 Child Growth Standard recommended weight-for-height as an indicator to evaluate wasting and $\mathrm{BMI}$ as an indicator to evaluate overweight and obesity. ${ }^{4}$ In the latest and revised WHO recommendation, weight-for-height is used as an indicator of overweight and obesity for preschoolers. ${ }^{5}$ In a previous study, BMI is widely used to evaluate overweight and obesity in sleep disturbance in children under 5 years old. ${ }^{6-10}$ Therefore, it is necessary to observe the differences of the two indicators for evaluation of growth.

Sleep is a factor that can affect children's growth and development. When sleeping, the function of organs increases, especially brain metabolism and hormones. A child has a longer duration of deep sleep and will decrease in age. ${ }^{11}$ Growth hormone (GH) which plays an important role in growth has increased secretion in non rapid eye movement (NREM) sleep phase, especially in stage II and IV (deep sleep)..$^{12}$ There are also changes in the secretion of cortisol hormones, thyroid stimulating hormone (TSH), ${ }^{13}$ leptin, and ghrelin, which will affect the growth of children and can lead to obesity if there is a disruption of sleep habits. ${ }^{14}$

The instrument for analyzing sleep disturbance easily is a questionnaire. One of the questionnaires that can assess sleep disturbance in children which has been validated and assessed for reliability is sleep disturbance Scale for children (SDSC). ${ }^{15}$ SDSC questionnaire has also been validated and assessed for reliability in Indonesian and has a sensitivity of $71.4 \%$ and a specificity of $54.5 \%$ in teenagers; thus SDSC instrument can be used as a screening tool for sleep disturbance. ${ }^{16}$ SDSC questionnaire assesses sleep habits in the past 6 months. This questionnaire was developed for children aged 6.5-15.3 years old. However, Bruni, et al. 2013 stated that statistical analysis, internal consistency, and factor analysis support the use of SDSC as an evaluation tool even at preschool age (3-6 years old). ${ }^{17}$

The effects of sleep disturbance on a child's health may include poor growth, influence on behavior and learning processes, worsening of mental health, and poor quality of life. In addition, many parents do not know about sleep problems in children; thus the important role of doctors is to identify the problem of sleeping in children early. ${ }^{18}$ Therefore, this study aimed to analyze the association between sleep disturbance and weight-forheight and BMI in preschoolers at three kindergartens in Kalijudan, Surabaya in March to September 2018.

\section{Methods}

This study used cross-sectional study design. In March to September 2018, measurement of body height and weight and distribution of questionnaires to parents of respondent were done in three kindergartens in Kalijudan, Surabaya. The questionnaires used were based on SDSC which had been validated and assessed for reliability and had been translated to Indonesian ${ }^{16}$. The measurement of body height and weight used microtoise and scale.

The exclusion criteria in this study were parents who did not want their children to be the sample and were unwilling to fill out the questionnaires and factors that biased the results of the data at the time of measurement; children who suffered from chronic pain in the last 6 months, and children who had spinal deformities, such as kyphosis, scoliosis, and lordosis.

Values and categories of weight-for-height Z-score (WHZ) and BMl-for-age Z-score (BAZ) refer to WHO Standard 2006 with growth categories and Z-score: very thin (<-3 SD); thin (-3 SD to <-2 SD); normal (-2 SD to 2 $\mathrm{SD}$ ); and overweight ( $>2 \mathrm{SD}$ ). The determination of the growth category and $\mathrm{WHZ}$ and $\mathrm{BAZ}$ values were calculated by the help of WHO Anthro application. ${ }^{4}$ Sleep disturbance was measured by SDSC questionnaire which has a 39 cutoff point. If the score is $>39$, the respondent had sleep disturbance and if the score was $\leq 39$, then the respondent did not have sleep disturbance. This questionnaire also assessed the types of sleep disturbances; disorders of initiating and maintaining sleep (DIMS), sleep breathing disorders (SBD), disorders of arousal nightmares (DA), sleep wake transition disorders (SWTD), disorders of excessive somnolence (DOES), and sleep hyperhydrosis $(\mathrm{SHY})^{15}$.

The analysis was performed to look at trends in the data with boxplot graphs and the association between sleep disturbances with weight-for-height and BMI measured by Mann-Whitney test and independent t-test with the help of data analysis program namely IBM SPSS 20.

\section{Results \\ Frequency distribution of respondents}

The data was collected from 86 respondents who were willing to participate in the study and fulfilled the inclusion criteria. In Table 1, most respondents were male with a percentage of $57 \%$, however, there was no significant difference between sex and sleep disturbance in preschoolers $(p=0.384)$. In Table 2 , preschoolers aged 3 4 years old experienced more sleep disturbance but there was also no significant association between age and sleep disturbance in preschoolers $(p=0.442)$.

There were many children who experienced sleep disturbance. In Table 3, 65.12\% preschoolers experienced sleep disturbance. The most common types of sleep disorders were SWTD (24.42\%) and DIMS (13.96\%).

The distribution of respondents by $\mathrm{WHZ}$ and $\mathrm{BAZ}$ (Table 4) category has the same number and percentage. 
Children with the highest category were children with normal category (Z-Score -2 SD to 2 SD) with a percentage of $66.28 \%$. To easily find the description of data distribution, data diversity, tendency of data and outlier data, the data obtained is displayed through a boxplot chart in Figure 1 and Figure 2. From the bloxpot chart, the distribution of data covers quite a wide range visible from the distance between the long top and bottom edge of Whiskers line. In the group of preschoolers who did not experience sleep disturbance, there is one outlier data; and in the group of preschoolers who experienced sleep disorders, there are four outlier data. Looking at the tendency of the data through boxes that describe $50 \%$ of the data, children who experienced sleep disturbance tend to have higher $\mathrm{WHZ}$ and $B A Z$ values than preschoolers who did not experience sleep disturbances.

\section{Analysis of the association between sleep disturbance} with weight-for-height and BMI

From Table 4, similar significance value of $0.226(p>$ 0.05 ) was obtained, meaning that there was no statistically significant association between sleep disturbance in WHZ and BAZ category. To determine the probability of the association between sleep disturbance with $\mathrm{WHZ}$ and $\mathrm{BAZ}$ through its distribution, independent t-test is performed if the sample data is normally distributed. This test uses the interval/ratio data scale from the value of sleep disturbance to the value of $\mathrm{WHZ}$ and $\mathrm{BAZ}$.

The results of the normality test using KolmogorovSmirnov test showed that the two independent variables had values of $p>0.05$, meaning that the data in this study is normally distributed and that independent t-test can be done. From Table 5, significance values of 0.524 and 0.490 were obtained $(p>0.05)$, meaning there was no significant association between sleep disturbances with $\mathrm{WHZ}$ and BAZ category in preschoolers aged 3-5 years old.

Table 1. The statistical analysis of the relationship between sleep disorders and gender $(n=86)$

\begin{tabular}{lccc}
\hline \multicolumn{1}{c}{ Sex } & $\begin{array}{c}\text { Sleep } \\
\text { disturbance }\end{array}$ & $\begin{array}{c}\text { No sleep } \\
\text { disturbance }\end{array}$ & $\mathbf{p}$ \\
\hline Male & $30(35 \%)$ & $19(22 \%)$ & \\
Female & $26(30 \%)$ & $11(13 \%)$ & $0.384^{*}$ \\
\hline
\end{tabular}

*) Chi-square test

Table 2. The results of statistical analysis of the relationship between sleep disorders and age $(n=86)$.

\begin{tabular}{cccc}
\hline Age & $\begin{array}{c}\text { Sleep } \\
\text { disturbance }\end{array}$ & $\begin{array}{c}\text { No sleep } \\
\text { disturbance }\end{array}$ & p \\
\hline $3-<4$ y.o. & $31(36 \%)$ & $14(16 \%)$ & \\
$4-5$ y.o. & $25(29 \%)$ & $16(19 \%)$ & $0.442^{*}$ \\
\hline
\end{tabular}

*) Chi-square test
Table 3. The frequency distribution based on sleep disturbance and types of sleep disturbance $(n=86)$.

\begin{tabular}{lcc}
\hline SDSC Questionnaire & $\begin{array}{c}\text { Total } \\
\text { (n) }\end{array}$ & $\begin{array}{c}\text { Percentage } \\
\text { (\%) }\end{array}$ \\
\hline No sleep disturbance & 30 & 34.88 \\
$\begin{array}{l}\text { Sleep disturbance } \\
\quad \text { Disorders of initiating }\end{array}$ & 56 & 65.12 \\
$\quad \begin{array}{l}\text { and maintaining sleep } \\
\text { (DIMS) }\end{array}$ & 12 & 13.96 \\
$\begin{array}{l}\text { Sleep breathing } \\
\text { disorders (SBD) }\end{array}$ & 1 & 1.16 \\
$\begin{array}{l}\text { Disorders of arousal } \\
\text { nightmares (DA) }\end{array}$ & 6 & 6.98 \\
$\begin{array}{l}\text { Sleep wake transition } \\
\text { disorders (SWTD) }\end{array}$ & 21 & 24.42 \\
$\begin{array}{l}\text { Disorders of excessive } \\
\text { somnolence (DOES) }\end{array}$ & 8 & 9.30 \\
$\begin{array}{l}\text { Sleep hyperhydrosis } \\
\text { (SHY) }\end{array}$ & 8 & 9.30 \\
\hline
\end{tabular}

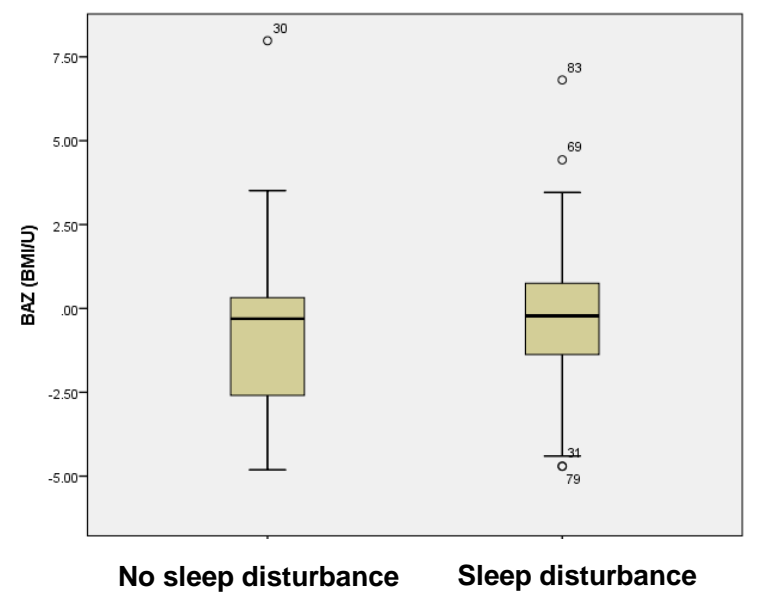

Figure 1. Boxplot chart between sleep disturbance with BAZ.

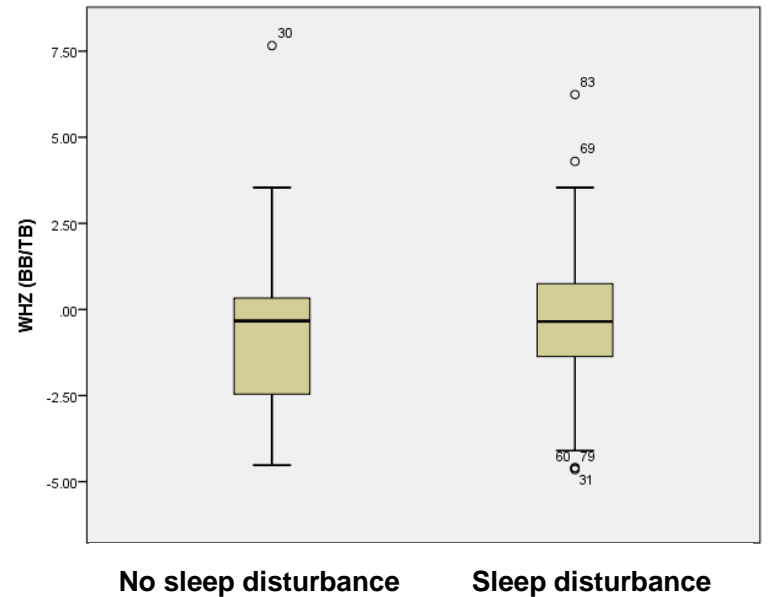

Figure 2. Boxplot chart between sleep disturbance with WHZ. 
Table 4. The results of statistical analysis of the association between sleep disturbance with the category of WHZ and BAZ.

\begin{tabular}{lccccc}
\hline \multirow{2}{*}{ Sleep disturbance } & \multicolumn{3}{c}{ WHZ and BAZ category $^{\star \star}$} & \multirow{2}{*}{ p } \\
\cline { 2 - 5 } & Very thin & Thin & Normal & Overweight & \\
\hline No sleep disturbance & 5 & 3 & 19 & 3 & \\
$\mathrm{n}(\%)$ & $(16.7 \%)$ & $(10 \%)$ & $(63.3 \%)$ & $(10 \%)$ & \multirow{2}{*}{$0.226^{*}$} \\
Sleep disturbance & 7 & 2 & 38 & 9 & \\
$\mathrm{n}(\%)$ & $(12.5 \%)$ & $(3.6 \%)$ & $(67.9 \%)$ & $(16.1 \%)$ & \\
\multicolumn{1}{c}{ Total } & 12 & 5 & 57 & 12 & \\
& $(14 \%)$ & $(5.8 \%)$ & $(66.3 \%)$ & $(14 \%)$ \\
\hline
\end{tabular}

*) Mann-Whitney test

${ }^{\star *}$ ) Weight-for-height z-score (WHZ) and BMI-for-age z-score (BAZ)

Table 5. The results of statistical analysis of the association between sleep disturbance with WHZ and BAZ.

\begin{tabular}{clcc}
\hline Variable & \multicolumn{1}{c}{ Sleep disturbance } & Mean \pm SD & p \\
\hline BB/TB & No sleep disturbance & $-0.608 \pm 2.45264$ & $0.524^{*}$ \\
& Sleep disturbance & $-0.2730 \pm 2.23934$ & \\
BMI/U & No sleep disturbance & $-0.5920 \pm 2.52490$ & $0.490^{*}$ \\
& Sleep disturbance & $-0.2207 \pm 2.27991$ & \\
\hline
\end{tabular}

*) independent t-test

\section{Discussion}

Based on the results of the study, it was found that males experienced more sleep disturbance than females. This is because males have shorter sleep duration than females. It has been observed that less slow-wave appeared in sleeping experienced by males rather than females. ${ }^{19}$ In the prevalence of studies on sleep habits in rats and mice, the differences in sex prevalence can be caused by the differences in sex hormones and sex chromosome modulation. ${ }^{20}$ Even so, the results of the analysis in this study showed no significant association between males and females with sleep disturbance. In the previous study, there was no correlation between sex and sleep patterns ${ }^{21,22}$, and sleep disturbance in preschoolers. ${ }^{23}$ Previous studies also found that there were no sex differences in sleep disturbance at ages up to 13 years old. Sex differences in sleep disturbance start in the beginning of children experiencing puberty between 15-24 years old. ${ }^{24}$

Likewise, with the results of the analysis based on the age, there was no statistically significant association between age and sleep disturbance. This result is different to the previous studies which stated that there was significant association between ages and sleep disturbance. ${ }^{23}$ This difference might happen as the age range of 3-5 years old is prone to frequent sleep disturbances which will affect sleep patterns, development, and future growth. ${ }^{21}$ Sleep patterns generally will also change, especially in young adults, due to changes in hormone secretion, one of which is a decrease in secretion of $\mathrm{GH}$ and slow wave sleep. ${ }^{25}$

From sleep disturbance questionnaires that had been distributed to the parents of the respondents, there were preschoolers who experienced more sleep disturbance than preschoolers who did not experience sleep disturbance. The most common types of sleep disorders were SWTD (24.42\%) and DIMS (13.96\%). In SDSC questionnaire, SWTD has several subtypes; hypnic jerks, rhythmic movement disorders, hypnagogic hallucinations, nocturnal hyperkinesias, sleep talking, and bruxism. DIMS also has several subtypes; sleep duration, sleep latency, going to bed reluctantly, difficulty in falling asleep, falling asleep anxiety, night awakenings, and difficulty in falling asleep after awakenings. ${ }^{15}$

Previous studies have found that sleep disturbance in children aged 3-5 years old in Canada experienced more problems starting and maintaining sleep and SWTD in subtypes of rhythmic movement disorder and bruxism ${ }^{26}$. In Australia, sleep disturbance in the 4-5 years old age range often occur and the most common is due to difficulty sleeping at night and waking up at night. Compared to children who do not have sleep disturbance, children with severe sleep disturbance have a lower quality of life, especially in terms of development and behavior of children. ${ }^{27}$ In addition, it is also found in Asian populations that children in Asia have much longer sleep times and shorter nights of sleep. ${ }^{28}$

In the first 5 years of life, a child will acquire new skills and abilities that can affect a child's sleep. At the age of 6 18 months, the child is developing an understanding of an object and can experience separation anxiety or difficulty parting with his parents and having difficulty calming down which causes sleep disturbances. In addition, obtaining gross motor skills may result in a negative impact on sleep habits. ${ }^{29}$

Children will also experience dramatic changes of sleep patterns in the first 5 years of life. Several factors that can affect sleep patterns in children that make them fall into sleep disturbance include child temperament and development, style or influence of parenting from parents, child-parent interaction, and environmental factors. The media also greatly affects the sleep patterns of children aged 3-5 years old, especially in the duration of sleep ${ }^{29}$.

According to data analysis that had been measured descriptively, the mean values of $\mathrm{WHZ}$ and $\mathrm{BAZ}$ of children experiencing sleep disturbance $(M=-0.27 ;-0.22)$ were 
higher than children without experiencing sleep disturbance $(\mathrm{M}=-0.61 ;-0.59)$. These results are also found in the previous studies; however, the average BMI values of children with sleep disturbance $(\mathrm{M}=0.08)$ and those who did not experience sleep disturbances $(\mathrm{M}=$ 0.05 ) were higher. ${ }^{23}$

Examining the tendency of the data through the boxes (Interquartil range $(\mathrm{IQR})=50 \%$ of data), children who experienced sleep disturbance tend to have higher $\mathrm{WHZ}$ and $B A Z$ values than children who did not experience sleep disturbances. The results of these tendencies are in accordance with the results of previous studies which stated that sleep disturbances, especially in short night sleep duration, are associated with higher BAZ. ${ }^{6}$. Higher values of $W H Z$ and $B A Z$ in preschoolers with short sleep duration might be a result of hormonal changes, such as decreased leptin, which can increase appetite and inappropriate association between leptin and cortisol which affect metabolism and lead to weight gain and obesity. ${ }^{30}$

Although there was a tendency, the results of nominal and categorical data that had been analyzed using MannWhitney test showed that there was no significant difference between sleep disturbance with $\mathrm{WHZ}$ and $\mathrm{BAZ}$ in preschoolers. In order to see the possible association through its distribution, sleep disturbances were analyzed in relation to $\mathrm{WHZ}$ and $\mathrm{BAZ}$ values with the scale data type using independent t-test. The results obtained are in accordance with the study of Hiscock. et al. in 2011, and it was found that there was no association between sleep disturbances, in this case is short sleep duration, and BMI starting from age 0 to groups of children aged 6-7 years old. ${ }^{31}$ This result is different to the meta-analysis study by Cappuccio, et al. in 2007 and other studies. ${ }^{32,6}$ This difference may occur due to several other factors that can affect sleep and the child's weight, including variations in gender, ethnicity, social and economic status, degree of energy intake, energy expenditure, and frequency of eating of children in which some of the mentioned variables are not examined in this study. ${ }^{32}$ In another study, it was also found that sleep can function as a barometer not only in physical health but also in the mental health of children. Sleep influences the child's temper, not having a chronic illness but taking drugs, as well as individual variations in circulation. A number of studies have found persistence and recurrence of sleep problems during infancy to childhood. ${ }^{33}$ The individual children history was not included in the exclusion criteria and could influence the results.

This study certainly has many limitations. Sleep disturbance were measured only by one method of measurement using SDSC questionnaire filled in by the parents. This questionnaire assesses if a child experiences sleep disturbance and the type of sleep disturbance that the child has. This cross sectional study did not describe sleep-wake patterns from time to time; thus it is less helpful to explain its association to sleep disturbance. It is important to be cautious in determining the sleep disturbance variable as a single causative factor because it is still considered wide among the types of sleep diturbances. ${ }^{33}$ In previous studies, short sleep duration affected body weight in children and there were no other sleep disturbance parameters related to the child's weight status $^{6}$. It is also different to the previous meta-analysis studies which showed that short sleep duration at 3 years of age would cause overweight and obese at 7 years of age with prospective and cohort studies. ${ }^{34}$

In this study, sleep disturbance were measured based on the reports and the views of the parents. The results of the sleep disturbance assessment were subjective because the parents could make estimation that were too low or too high when answering the types of questions about their children's sleeping habits ${ }^{31}$

\section{Conclusion}

There was no statistically significant association between sleep disturbance with $\mathrm{WHZ}$ and $\mathrm{BAZ}$ in preschoolers aged 3-5 years old; however, descriptively, the values of $W H Z$ and $B A Z$ in the group of preschoolers who had sleep disturbance tended to be higher. Further research or studies can be conducted by using more prospective studies with more objectives and more accurate instruments to measure children sleep disturbance such as actigraphy.

\section{CONFLICT OF INTEREST}

The author stated there is no conflict of interest in this study.

\section{REFERENCES}

1. WHO. Obesity and Overweight [Internet]. 2016 [cited 2017 Jun 28]. Available from: http://www.who.int/en/newsroom/fact-sheets/detail/obesity-and-overweight

2. Kemenkes RI. InfoDATIN-Situasi Balita Pendek [document in Internet]. 2016 [cited 2017 Jun 28]. Available from:

http://www.depkes.go.id/resources/download/pusdatin/info datin/situasi-balita-pendek-2016.pdf

3. Wang $Y$, Zhou H, Zhang $Y$, Huang $X$, Yang $Y$, Liu X, et al. Double Burden of Malnutrition among Children under 5 in Poor Areas of China. PLoS One [Internet]. 2018 [cited 2017 Jun 24];13(9):1-12. Available from: https://journals.plos.org/plosone/article $? \mathrm{id}=10.1371 /$ journa I.pone.0204142

4. WHO. WHO Child Growth Standards: Training Course on Child Growth Assessment. Geneva: WHO Press; 2008. 5. WHO. Obesity and Overweight [Internet]. 2018 [cited 2018 Nov 26]. Available from: http://www.who.int/newsroom/fact-sheets/detail/obesity-and-overweight

6. Pattinson CL, Smith SS, Staton SL, Trost SG, Thorpe KJ. Investigating the Association between Sleep Parameters and the Weight Status of Children: Night Sleep Duration Matters. Sleep Heal [Internet]. 2018 [cited 2017 Jun 16];4(2):147-53. Available from: https://doi.org/10.1016/j.sleh.2017.12.009

7. Ash T, Taveras EM. Associations of Short Sleep Duration with Childhood Obesity and Weight Gain: Summary of a Presentation to the National Academy of 
Science's Roundtable on Obesity Solutions. Sleep Heal [Internet]. 2017 [cited 2017 Jun 10];3(5):389-92. Available from: http://dx.doi.org/10.1016/j.sleh.2017.07.008

8. Pongcharoen $\mathrm{T}$, Judprasong $\mathrm{K}$, Jitngarmkusol $\mathrm{S}$, Kriengsinyos W, Winichagoon P. Body Mass Index is associated with Fat Mass in Normal, Overweight/Obese, and Stunted Preschool Children in Central Thailand. Asia Pac J Clin Nutr. 2017 [cited 2017 Jun 24];26(4):686-91.

9. de Ruiter I, Olmedo-Requena R, Sánchez-Cruz JJ, Jiménez-Moleón JJ. Changes in Sleep Duration in Spanish Children Aged 2-14 Years from 1987 to 2011 [cited 2017 Jun 10]. Sleep Med [Internet]. 2016;21:145-50. Available from: http://dx.doi.org/10.1016/j.sleep.2015.12.021 10. Marfuah D, Hadi H, Huriyati E. Durasi dan Kualitas Tidur Hubungannya dengan Obesitas pada Anak Sekolah Dasar di Kota Yogyakarta dan Kabupaten Bantul. Jurnal Gizi dan Dietetik Indonesia [Internet]. 2013 [cited 2017 Jun 24];1(2):93-101. Available from: http://ejournal.almaata.ac.id/index.php/IJND/article/view/4 $4 / 0$

11. Ropper A, Brown R. Principles of Neurology. 8th ed. United States of America: McGraw-Hill; 2005.

12. Hall JE. Guyton and Hall Textbook of Medical Physiology. 13th ed. Philadelphia, PA: Elsevier Inc.; 2016. 13. Cauter E, Knutson K, Leproult R, Spiegel K. The Impact of Sleep Deprivation on Hormones and Metabolism. [Internet]. Vol. 7, Medscape Neurology. 2005 [cited 2017 Jun 28]. p. 1-9. Available from: https://www.medscape.org/viewarticle/502825

14. Taheri S, Lin L, Austin D, Young T, Mignot E. Short Sleep Duration is associated with Reduced Leptin, Elevated Ghrelin, and Increased Body Mass Index. PLoS Med [Internet]. 2004 [cited 2017 Jun 28];1(3):210-7. Available from:

https://journals.plos.org/plosmedicine/article?id=10.1371/j ournal.pmed.0010062

15. Bruni O, Ottaviano S, Guidetti V, Romoli M, Innocenzi $M$, Cortesi F, et al. The Sleep Disturbance Scale for Children (SDSC) Construction and Validation of an Instrument to Evaluate Sleep Disturbances in Childhood and Adolescence. J Sleep Res [Internet]. 1996 [cited 2017 Jun 28];5(4):251-61. Available from: https://onlinelibrary.wiley.com/doi/abs/10.1111/j.13652869.1996.00251.x

16. Natalia C, Sekartini R, Poesponegoro H. Skala Gangguan Tidur untuk Anak (SDSC) sebagai Instrumen Skrining Gangguan Tidur pada Anak Sekolah Lanjutan Tingkat Pertama. Sari Pediatr [Internet]. 2011 [cited 2017 Jun 28];12(6):365-72. Available from: https://saripediatri.org/index.php/sari-

pediatri/article/view/497

17. Romeo DM, Bruni O, Brogna C, Ferri R, Galluccio C De Clemente V, et al. Application of the Sleep Disturbance Scale for Children (SDSC) in Preschool Age. Eur J Paediatr Neurol [Internet]. 2013 Jul 1 [cited 2017 Jun 28];17(4):37482. Available from: https://www.sciencedirect.com/science/article/pii/S109037 9813000020

18. Martin J, Hiscock $H$, Hardy $P$, Davey B, Wake M. Adverse Associations of Infant and Child Sleep Problems and Parent Health: An Australian Population Study. Pediatrics [Internet]. 2007 [cited 2017 Jun 28];119(5):947$55 . \quad$ Available from: http://pediatrics.aappublications.org/cgi/doi/10.1542/peds. 2006-2569

19. Knutson KL. Sex Differences in the Association between Sleep and Body Mass Index in Adolescents. J Pediatr [Internet]. 2005 Dec [cited 2018 Oct 16];147(6):830-4. Available from:
http://linkinghub.elsevier.com/retrieve/pii/S002234760500 6906

20. Mallampalli MP, Carter CL. Exploring Sex and Gender Differences in Sleep Health: A Society for Women's Health Research Report. J Women's Heal [Internet]. 2014 [cited 2018 Oct 9];23(7):553-62. Available from: http://online.liebertpub.com/doi/abs/10.1089/jwh.2014.481 6

21. Duraccio KM, Jensen CD. Associations between Physical and Sedentary Activity Regularity and Sleep in Preschoolers and Kindergartners. Sleep Heal [Internet]. 2017 [cited 2018 Oct 16];3(4):263-8. Available from: http://dx.doi.org/10.1016/j.sleh.2017.04.001

22. Gupta R, Dutt S, Goel D, Mittal N, Dhyani M. SleepPatterns, Co-Sleeping and Parent's Perception of Sleep among School Children: Comparison of Domicile and Gender. Sleep Sci [Internet]. 2016 [cited 2018 Oct 9];9(3):192-7. Available from: http://dx.doi.org/10.1016/j.slsci.2016.07.003

23. Zahara DS, Hartanto F, Adyaksa G. Hubungan antara Gangguan Tidur dengan Pertumbuhan pada Anak Usia 36 Tahun di Kota Semarang [document on the Internet]. 2013 [cited 2018 Oct 17]; Available from: https://media.neliti.com/media/publications/109498-IDhubungan-antara-gangguan-tidur-dengan-pe.pdf 24. Mong JA, Baker FC, Mahoney MM, Paul KN, Schwartz MD, Semba K, et al. Sleep, Rhythms, and the Endocrine Brain: Influence of Sex and Gonadal Hormones. J Neurosci [Internet]. 2012 [cited 2018 Oct 14];31(45):16107-16. Available from: https://www.ncbi.nlm.nih.gov/pmc/articles/PMC3249406/ 25. Cauter E Van, Leproult R, Plat L. Age-Related Changes in Slow Wave Sleep and REM Sleep and Relationship with Growth Hormone and Cortisol Levels in Healthy Men. J Am Med Assoc [Internet]. 2000 [cited 2018 Oct 14];284(7):8618. Available from: https://jamanetwork.com/journals/jama/fullarticle/192981 26. Petit D, Touchette E, Tremblay RE, Boivin M, Montplaisir J. Dyssomnias and Parasomnias in Early Childhood. Pediatrics [Internet]. 2007 [cited 2018 Oct 15];119(5):e1016-25. Available from: http://pediatrics.aappublications.org/cgi/doi/10.1542/peds. 2006-2132

27. Hiscock $\mathrm{H}$, Canterford L, Ukoumunne OC, Wake M. Adverse Associations of Sleep Problems in Australian Preschoolers: National Population Study. Pediatrics [Internet]. 2007 [cited 2018 Oct 15];119(1):86-93. Available from:

http://pediatrics.aappublications.org/cgi/doi/10.1542/peds. 2006-1757

28. Mindell JA, Sadeh A, Kwon R, Goh DYT. Corrigendum to "Cross-Cultural Differences in the Sleep of Preschool Children" [Sleep Medicine 14, 12, (2013), 1283-1289], 10.1016/j.sleep.2013.09.002. Sleep Med [Internet]. 2014 [cited 2018 Oct 15];15(12):1595-6. Available from: http://dx.doi.org/10.1016/j.sleep.2014.09.001

29. Bathory E, Tomopoulos S. Sleep Regulation, Physiology and Development, Sleep Duration and Patterns, and Sleep Hygiene in Infants, Toddlers, and Preschool-Age Children. Curr Probl Pediatr Adolesc Health Care [Internet]. 2017 [cited 2018 Oct 9] ;47(2):29-42. Available http://dx.doi.org/10.1016/j.cppeds.2016.12.001

30. Spiegel K, Leproult $R$, L'Hermite-Balériaux $M$, Copinschi G, Penev PD, Van Cauter E. Leptin Levels are Dependent on Sleep Duration: Relationships with Sympathovagal Balance, Carbohydrate Regulation, Cortisol, and Thyrotropin. J Clin Endocrinol Metab [Internet]. 2004 [cited 2018 Oct 16];89(11):5762-71. 
Available

from:

https://academic.oup.com/jcem/article/89/11/5762/284474 4

31. Hiscock H, Scalzo K, Canterford L, Wake M. Sleep Duration and Body Mass Index in 0-7-Year Olds. Arch Dis Child [Internet]. 2011 [cited 2018 Oct 16];96(8):735-9. Available from: https://adc.bmj.com/content/96/8/735.long 32. Cappuccio FP, Taggart FM, Kandala N, Currie A, Chb MB, Peile E, et al. Meta-Analysis of Short Sleep Duration and Obesity in Children and Adults. Sleep [Internet]. 2008 [cited 2018 Oct 16];31(5):619-26. Available from: https://academic.oup.com/sleep/articleabstract/31/5/619/2454190
33. Ivanenko A, Gururaj BR. Classification and Epidemiology of Sleep Disorders. Child Adolesc Psychiatr Clin N Am [Internet]. 2009 [cited 2018 Oct 24];18(4):83948. Available from: https://www.sleep.theclinics.com/article/S1556407X(07)00058-6/abstract

34. Chen X, Beydoun MA, Wang Y. Is Sleep Duration Associated with Childhood Obesity? A Systematic Review and Meta-analysis. Obesity [Internet]. 2008 [cited 2018 Oct 16];16(2):265-74. Available http://doi.wiley.com/10.1038/oby.2007.63

from: 